\title{
A Speech Act Analysis of Hyperactive Children at Pradnyagama Theraphy Center
}

\author{
Anak Agung Ayu Krisnadiari ${ }^{1}$, I Wayan Pastika², I Gusti Ayu Gede Sosiowati ${ }^{3}$ \\ ayukrisnadiari@gmail.com,wayanpastika@unud.ac.id, sosiowati@yahoo.com \\ Udayana University, Denpasar, Indonesia
}

\begin{abstract}
The entitled of this study is "A Speech Act Analysis of Hyperactive Children at Pradnyagama Theraphy Center". The aim of the study is to describe the speech act of hyperactive children at Pradnyagama Theraphy Center. Hyperactivity can also be described as a physical state in which a person is abnormally and easily excitable or exuberant. Strong emotional reactions, impulsive behavior, and a short span of attention are also typical for a hyperactive person. The kids who are hyperactive are fidgety, restless, and easily bored. They may have trouble sitting still, or staying quiet when needed. They may rush through things and make careless mistakes. Hyperactivity can be caused by mental or physical conditions. The theory used in this study is from J.L Austin about Speech Acts. The data were taken from the caregiver and the hyperactive child at Pradnyagama Theraphy Center. The method use to analyze the data is qualitative. The techniques to collect the data: First, listening and taking notes the explanation of the caregiver about the hyperactive children. Second, observing the act of the hyperactive children and taking notes their speech act while they were talking and playing. Furthermore, the techniques to analyze the data were by classifying it into speech act component then analyze it using the relevant theory. In this research, there are 5 types of speech acts found in the conversation between the caregiver and the hyperactive children like giving command, questioning, suggesting, requesting, and threatening.
\end{abstract}

Keywords: Speech Act, Hyperactive Children, Mental Disorder

\section{Introduction}

Mental disorders can be define as any illness with significant psychological or behavioral manifestations that is associated with either a painful or distressing symptom or an impairment in one or more important areas of functioning. There is no simple definition of mental disorder that is universally satisfactory. This is partly because mental states or behavior that are viewed as abnormal in one culture may be regarded as normal or acceptable in another, and in any case it is difficult to draw a line clearly demarcating healthy from abnormal mental functioning. One of the most common mental disorders experienced by children is hyperactivity.

According to Merriam Webster, Hyperactive can be defined as an attitude that is more active than is usual or desirable. Hyperactivity can also be described as a physical state in which a person is abnormally and easily excitable or exuberant. Strong emotional reactions, impulsive behavior, and a short span of attention are also typical for a hyperactive person. The kids who are hyperactive are fidgety, restless, and easily bored. They may have trouble sitting still, or staying quiet when needed. They may rush through things and make careless mistakes. They may climb, jump, or roughhouse when they shouldn't. Hyperactivity can be caused by mental or physical conditions. For example, conditions that affect your nervous system or thyroid may contribute to it. The Characteristics of the hyperactive children's language are first, stammered which means that when the hyperactive children talk to people, they may sound stammered because their spelling is not as good as normal people; second, in conveying the wishes, hyperactive children tend to say one word that is often repeated; third, in conveying a wish, the hyperactive children are sometimes asking for it with a crying or angry expression without uttering words; and the last one is when the hyperactive children cannot get what they want, they will get mad by calling their parents or people that is close to them in their life loudly. 
The most common causes are: ADHD Attention-deficit/hyperactivity disorder (ADHD) is a chronic condition that affects millions of children and often continues into adulthood. ADHD includes a combination of persistent problems, such as difficulty sustaining attention, hyperactivity and impulsive behavior. Some of the hyperactive children may have problems with their language or communication like the way they talk to people, etc. Communication has always been a necessity in human life. Through communication, the trade of thought among people, which directly contributes to the development of the quality of life itself, can be performed. Pragmatics is a study which belief is what is communicated is more than what is said. The utterances that the speakers produce in communication contain deeper sense than the actual meaning of the words or phrases themselves. One of the scopes of pragmatics is speech act. Yule (1996) states that speech acts are a study of how the speakers and hearers use language. Bach (1979) explains that an action in verbal communication has message in itself, so the communication is not only about language but also with action. In conclusion speech act is the utterance that occurs and act refers to an action. In this research, the focused is only about the analysis speech act of hyperactive children like the way they talk to people when they are saying something, anger, apologizing, making promises, etc. because of that I'm interest to make a research about it. The purpose of the study is to describe the speech act of hyperactive children at Pradnyagama Theraphy Center.

\section{Theoretical Framework}

Leech (983: 6) states that pragmatics is the study of meaning which is related to the speech situations. In accordance to Leech statement, Yule (1996) argues that pragmatics should also consider aspects of context such as who people are talking to, when, where, and under what circumstances that will determine the way they say and what they want to say. One of the scopes of pragmatics study is speech act.

The speech act theory considers language as a sort of action rather than a medium to convey and express. The contemporary Speech act theory developed by J. L. Austin a British philosopher of languages, he introduced this theory in 1975 in his well-known book of 'How do things with words'. Later John Searle brought the aspects of theory into much higher dimensions. This theory is often used in the field of philosophy of languages. Austin is the one who came up with the findings that people not only uses that language to assert things but also to do things and people who followed him went to greater depths based on this point.

Further Austin divides his linguistic act into three different categories. They are:

a. Locutionary act - This is the act of saying something. It has a meaning and it creates an understandable utterly to convey or express.

b. Illocutionary act - It is performed as an act of saying something or as an act of opposed to saying something. The illocutionary utterance has a certain force of it. It well-versed with certain tones, attitudes, feelings, or emotions. There will be an intention of the speaker or others in illocutionary utterance. It is often used as a tone of warning in day today life.

c. Perlocutionary act - It normally creates a sense of consequential effects on the audiences. The effects may be in the form of thoughts, imaginations, feelings or emotions. The effect upon the addressee is the main character ship of perlocutionary utterances.

Speech acts can be classified into five categories as Searle in Levinson (1983: 240) states that the classifications are representatives, directives, commissives, expressive, and declarations.

a. Representatives

Representatives are speech acts that the utterances commit the speaker to the truth of the expressed proposition. The utterances are produced based on the speaker's observation of certain things then followed by stating the fact or opinion based on the observation. When someone says "she's beautiful", the speaker can state the sentence based on the fact or just give his or her own opinion about physical condition of a person. It also states what the speaker believes to be the case or not.

Statements of fact, assertions, conclusions, and descriptions are all examples of the speaker representing the world as he or she believes it is. For example when someone says "The earth is flat", it represents the speaker's assertions about the earth. The speaker has opinion that the earth is flat. Representatives' speech act can be noted by some speech acts verb, such as: remind, tell, assert, deny, correct, state, guess, predict, report, describe, inform, insist, assure, agree, claim, beliefs, conclude.

b. Directives

Directives area speech acts that speaker uses to get someone else to do something. These speech acts include requesting, questioning, command, orders, and suggesting. For example, when someone says 
"Could you lend me a pencil, please?" the utterance represents the speaker requests that the hearer to do something which is to lend him a pencil.

c. Commissives

Commissives are speech acts that the utterances commit the speaker to some future course of action, these include promising, threatening, offering, refusal, pledges. For example when someone says "I'll be back", represents the speaker's promise that he/she will be back.

d. Expressive

Expressive are speech acts that the utterances express a psychological state. These speech acts include thanking, apologizing, welcoming, and congratulating. For example, when someone says "don't be shy; my home is your home." The utterance represents the speaker's expression that he/she welcomes someone.

e. Declarations are speech acts that the utterances effect immediate changes in the institutional state of affairs and which tend to rely on elaborate extra- linguistic institutions. These speech acts include excommunicating, declaring war, christening, firing from employment. For example "you are dead to me."

\section{Research Methods}

The research of the study is focuses on the speech act of hyperactive children at Pradnyagama Theraphy. The primary data were taken from the caregiver about the hyperactive children at Pradnyagama theraphy. Her name is Mrs. Ayu Andini. Then, the secondary data were taken from some of the hyperactive children especially their speech act. The data is in Indonesian language. There are 3 hyperactive children as the data to be observing. I choose three hyperactive children to be observing because it will be easier to do the observation especially to reduce the noises from the other hyperactive children who will disturb the process of the research. I will choose 3 children who are the most hyperactive according to the caregiver there. The age of the hyperactive children are around $2-4$ years old because most of the hyperactive children in there are having age around it. The role of the caregiver at Pradnyagama Theraphy is as the one looking after the kids as well as a teacher. The method use to analyze the data is qualitative. The techniques to collect the data: First, listening and taking notes the explanation of the caregiver about the hyperactive children. Second, observing the act of the hyperactive children and taking notes their speech act while they were talking and playing. Furthermore, the techniques to analyzing the data was by classifying it into speech act component then analyze it using the relevant theory. Pradnyagama theraphy Center is located at Jln. Tukad Yeh Aya no. 183, Renon.

\section{Result and Discussion}

Based on the data analysis, it can be concluded that there are 5 types of speech acts found from the hyperactive children on Pradnyagama Theraphy. Generally, some of the hyperactive children having problem in speaking like speech delay so that when they were wanting something, they can't tell it in a normal way instead of they were behave strangely to get the attention or to get something they want. However, there are some hyperactive children who are able to speak but only a word or two.

\subsection{Conversation 1}

Caregiver: gak boleh, Ira! Itu bukan botol minum, Ira.

Ira (the hyperactive child): Yelling... MAMA! (Crying and throw herself on the ground then pointing the bottle)

The explanation: In this conversation the caregiver tries to prohibit Ira to take the bottle because it's not Ira's. But Ira refused it then she try to take it by calling her mom (yelling) because she thinks that her mom will help her to take that bottle. The locutionary act in this conversation is said by caregiver "gak boleh, Ira! Itu bukan botol minum, Ira". The illocutionary act is directives (giving command) in this context, the caregiver giving a command to Ira. Furthermore, the perlocutionary act in this conversation is the expression of Ira (the hyperactive child) or the effect of the caregiver's command, Ira refused it by yelling, crying and then calling her mom because she thinks that her mom will help her to get the bottle. 


\subsection{Conversation 2}

Caregiver: duduk dulu ya, jangan lari-lari! Ica maunya apa, sekarang? main puzzle ya.

Ica (the hyperactive child): (Sit down) Ma-in... main..

The explanation: In this conversation the caregiver tries to ask Ica about what is she wants then give her suggestion to play puzzle and then she said that she wants to play it. The locutionary act in this conversation is the utterance said by caregiver "Ica maunya apa, sekarang? main puzzle ya" and then the illocutionary act is directives (questioning and suggesting) by the caregiver. The perlocutionary act is Ica's expression then she said "Ma-in... main". In this context, Ica was agreed with her caregiver's suggestion that she wants to play puzzle at that time.

\subsection{Conversation 3}

Ica (the hyperactive child): mau su-su... susuu (yelling and then crying)

Caregiver: ayo coba cari dulu ditasnya ada gak? Jangan nangis, ayo cari dulu! (Looking for the milk in Ica's bag)

The explanation: In this conversation the hyperactive children (Ica) wants a milk then tell it to her caregiver by saying "su-su" which means milk in English. And then her caregiver tells her to search it in her bag. The locutionary act is the utterance said by Ica (the hyperactive child) "mau su-su... susuu". The illocutionary act is directives (requesting) said by Ica. Then, the perlocutionary act is the caregiver's expression that she tells Ica to stop crying and tries to search it in her bag.

\subsection{Conversation 4}

Gungde (the hyperactive children): Gak... gak ma-u (trying to throw a ball towards his caregiver)

Caregiver: aduh.. gak boleh gungde gitu. Gungde mau apa?

The explanation: In this conversation the hyperactive children (Gungde) trying to intimidate his caregiver by throwing a ball towards his caregiver. Then, his caregiver was asking him what he wants. The locutionary act in this conversation is "Gak... gak ma-u (trying to throw a ball towards his caregiver)" said by Gungde. The illocutionary act is Commissives (threatening). Then, the perlocutionary act is the caregiver's expression when she prohibits Gungde to do that.

\subsection{Conversation 5}

Ica (the hyperactive child): aem... aem (pointing to her rice bowl)

Caregiver: Ica mau maem ya. Okee duduk dulu ya. Duduk dulu.

The explanation: in this conversation Ica (the hyperactive children) wants to eat and then she said "aem..aem" to her caregiver, which means "eat". Then, her caregiver said to her that she must sit calmly before she gets her meal. The locutionary act is "aem... aem (pointing to her rice bowl)". The illocutionary act is directives (requesting) said by Ica. Then, the perlocutionary act is the caregiver's expression when she tells Ica to sit calmly before eat her meal.

\subsection{Conversation 6}

Ira (the hyperactive child): tak.. tak.. tak (Pointing her caregiver's juice)

Caregiver: Ira mau ini. Boleh.. (Give her juice to Ira) 
The explanation: in this conversation Ira (the hyperactive child) wants her caregiver's juice by saying "tak" instead of "minta" which means requesting it. Then, her caregiver gave her the juice. The locutionary act in this conversation is "tak.. tak.. tak (Pointing her caregiver's juice)". The illocutionary act is directives (requesting) said by Ira. Then, the perlocutionary act is the caregiver's reaction; in this conversation the caregiver gave her a juice.

\subsection{Conversation 7}

Caregiver: oke duduk dulu ya. Ada yang tau gak ini gambar apa? (Showing part of the puzzle with an octopus picture in it)

Gungde (the hyperactive child): gu-ri-ta.... Then he grabs it from his caregiver's hand.

The explanation: in this conversation the caregiver asking Gungde about the picture in a part of the puzzle and then Gungde (the hyperactive child) stuttered to answer the question. The locutionary act in this conversation is "Ada yang tau gak ini gambar apa?" Then, the illocutionary act is directives (questioning). The perlocutionary act is Gungde's reaction when he stuttered to answer his caregiver's question.

\subsection{Conversation 8}

Ica (the hyperactive children): Mmen... mmenn (Pointing a candy on the table)

Caregiver: iya boleh ambil aja

The explanation: in this conversation Ica wants a candy by saying "mmen" instead of "permen". Then, her caregiver gives her the candy. The locutionary act is "Mmen... mmenn". Then, the illocutionary act is directives (requesting) said by Ica. The perlocutionary act is the caregiver's reaction in this conversation.

\subsection{Conversation 9}

Ira (the hyperactive child): ma-u... tu. (Yelling and crying) (Pointing a flower and then hit her caregiver)

Caregiver: ndak boleh.. kotor itu, ra.

The explanation: in this conversation Ira wants a flower but her caregiver prohibits her because the flower is dirty. Then, Ira gets mad and hit her caregiver with her hand. The locutionary act is "ma-u... tu. (Yelling and crying) (Pointing a flower and then hit her caregiver)". Then, the illocutionary act is directives (requesting) and Commissives (threatening). The perlocutionary act is the caregiver's reaction when she tries to prohibit Ica to take the flower.

\subsection{Conversation 10}

Ira (the hyperactive child): (hearing some noises outside the class when she plays puzzle in the class) pa tu?

Caregiver: itu orang jalan diluar. Ayo selesaiin dulu puzzlenya.

The explanation: in this conversation Ira asks her caregiver about the noises outside her class. Then, her caregiver said that it just people walking outside the class and asks Ira to finish her puzzle first. The locutionary act is "(hearing some noises outside the class when she plays puzzle in the class) pa tu?" said by Ira. The illocutionary act is directives (questioning). Then, the perlocutionary act is the caregiver's reaction.

\subsection{Conversation 11}

Caregiver: Ica, turun! Nanti jatuh. Jangan naik kesana!

Ica (the hyperactive child): hahaha (Get off from the table) 
The explanation: in this conversation the caregiver give a command to Ica to get off from the table and then Ica obeys her. The locutionary act in this conversation is "Ica, turun! Nanti jatuh. Jangan naik kesana!" said by the caregiver. The illocutionary act is directives (giving command). The perlocutionary act is Ica's reaction.

\subsection{Conversation 12}

Caregiver: Taruh gung! tak bilang sama nininya nanti ya.

Gungde (the hyperactive child): Yelling.. ngak au....

The explanation: in this conversation the caregiver give a command to Gungde to put the mirror down but he won't to do it. The locutionary act is "Taruh gung! tak bilang sama nininya nanti ya" said by the caregiver. The illocutionary act is directives (giving command). Then, the perlocutionary act is Gungde's reaction.

\subsection{Conversation 13}

Caregiver: itu ambil lagi pensilnya, ca!

Ica (the hyperactive child): inii... (give the pencil to her caregiver)

The explanation: in this conversation the caregiver give a command to Ica to take the pencil then she takes it and gives it to her caregiver. The locutionary act is "itu ambil lagi pensilnya, ca!" said by the caregiver. The illocutionary act is directives (giving command). Then, the perlocutionary act is Ica's reaction.

\subsection{Conversation 14}

Caregiver: Siapa yang mau ini?

Gungde (the hyperactive child): akuu... (Raise his hand)

The explanation: in this conversation the caregiver asks about who wants a cup of tea on the table and then Gungde (the hyperactive child) raise his hand which means he wants a cup of tea on the table. The locutionary act is "Siapa yang mau ini?" said by the caregiver. The illocutionary act is directives (questioning). Then, the perlocutionary act is Gungde's reaction.

\subsection{Conversation 15}

Caregiver: Ira, mau ini? (Showing a candy to her)

Ira (the hyperactive child): au...

The explanation: in this conversation the caregiver asks Ira about a candy and then she said "au" instead of "mau" which means "she wants a candy". The locutionary act is "Ira, mau ini?" said by the caregiver. The illocutionary act is directives (questioning). Then, the perlocutionary act is Ira's reaction. In this conversation, Ira said that she wants the candy.

\section{Conclusion}

Based on the result of the study, there are 5 types of speech act found from the conversation between the caregiver and the hyperactive children, like giving command, questioning, suggesting, requesting, and threatening. The classification of the speech act were found in the conversation are directives and commissives. Generally, some of the hyperactive children having problem in speaking like speech delay so that when they were wanting something, they can't tell it in a normal way instead of they were behave strangely to get the attention or to get something they want.

However, there are some hyperactive children who are able to speak but only a word or two. Because of that, it's hard to understand them or knowing what they want while they were speaking. The kids 
who are hyperactive are fidgety, restless, and easily bored. They may have trouble sitting still, or staying quiet when needed. They may rush through things and make careless mistakes. They may climb, jump, or roughhouse when they shouldn't. Hyperactivity can be caused by mental or physical conditions. For example, conditions that affect your nervous system or thyroid may contribute to it. The most common causes are: ADHD. Attentiondeficit/hyperactivity disorder (ADHD) is a chronic condition that affects millions of children and often continues into adulthood. The hyperactive children as a secondary data in this study (Ira, Ica and Gungde) suffer ADHD or Attention Deficit/ Hyperactivity Disorder.

\section{Acknowledgements}

I would like to thank to Udayana University and Pradnyagama Therapy Center for the supports to accomplish this research.

\section{References}

Claiborn, Charles D. Mental Disorder. Arizona State University Available From: Britannica.com

Hidayat, Agus. 2016. Speech Acts: Force Behind Words. Lampung

Saifudin, Akhmad. 2019. Teori Tindak Tutur Dalam Studi Linguistik Pragmatik. Universitas Dian Nuswantoro.

Jodai, Hojat. 2011. An Introduction to Psycholinguistic. The University of Guilan.

Khairi, Husnuzziadatul. 2018. Upaya Guru Dalam Meningkatkan Perkembangan Sosial Emosional Anak Attention Deficit Hyperactivity Disorder (ADHD) di PAUD Inklusi Yogyakarta. Fakultas Ilmu Tarbiyah dan Keguruan UIN.

Kant, Immanuel. 2004. Crítica de la razónpura. RBA Editores.

Kurniawati, Wati. 2017. Acquisition of Language in Hyperactivity Children Hard Focus. Badan Pengembangan dan Pembinaan Bahasa.

Martinez del Castillo, Jesus. 2015. The Speech Act as an Act of Knowing. Department of Philology: Faculty of Business Studies and Tourism, Universidad de Almaria, Spain.

Narula, Uma. 2006. Dynamics of Mass Communication: Theory and Practice. New Delhi.

NHS. 2018. Symptoms (ADHD). United Kingdom

Available From. www.nhs.uk 